\title{
Pantawid Pamilyang Pilipino Program (4Ps): Its Effect on the Academic Performance of Student-Beneficiaries in Calaba National High School in the Philippines
}

\author{
Marc Jon S Flores \\ Calaba National High School, Philippines \\ Christine Alaine B Espinoza \\ Dr. Paulino J. Garcia Memorial Research and Medical Center \\ Harold C Enrico \\ Civil Service Commission-Aurora Field Office \\ Rosemarie R Casimiro \\ Nueva Ecija University of Science and Technology, Philippines
}

Received: May 9, 2019 Accepted: June 3, 2019 Online published: June 12, 2019

doi:10.5296/jpag.v9i2.14762 URL: https://doi.org/10.5296/jpag.v9i2.14762

\begin{abstract}
This study measured and evaluated the effect of Pantawid Pamilyang Pilipino Program (4Ps) on the academic performance of the student-beneficiaries of Calaba National High School, Calaba, San Isidro, Nueva Ecija in the Philippines. Survey questionnaires were distributed to ninety five 4Ps student beneficiaries who were purposively selected based on the following criteria: 4Ps beneficiary, enrolled in Calaba National High School at the time of data gathering, and willingness to participate in the study. Analysis of all collected data revealed the significant effect of the program to the performance of student beneficiaries especially in motivating students to attend classes. The result also supports Vroom's Expectancy Theory which assumes that the students' efforts, performance, and behavior are influenced by the importance they place on the desired outcome. In this case, to satisfy the conditionalities and remain eligible for the cash grant which have positive effect on the socio-economic status of
\end{abstract}


their family. Based on the findings, it is therefore recommended that the scope of the program be extended especially that two years have been added to the secondary education; livelihood programs be intensified to provide family-beneficiaries with additional income; and for the concerned agencies and authorities to review the existing budget and disbursement schemes to prevent delay in the release of grants. The increase in the school attendance of students and the diminished drop-out rate indicates the program's positive effect on the lives of the beneficiaries.

Keywords: education, social program, motivation, expectancy theory

\section{Introduction}

A large percentage of the Philippine population has been affected by poverty for many years now (Reyes et al., 2014). As such, the government with an aim to at least minimize poverty prevalence has introduced various social programs and policies. However, because most are attached to single-focus solutions, they have proven to be ineffective and not sustainable (Son and Florentino, 2008). Not until year 2008 when Pantawid Pamilyang Pilipino Program (4Ps), one of the most popular social measures adopted by the country was implemented (Dungog-Cuizon and Cuizon, 2016).

The Philippine government, through the 4Ps, provides conditional cash grants to the marginalized or to the "poorest of the poor" to improve the health, nutrition, and the education of children aged 0 to 18 (Reyes et al., 2013). The program is patterned after the conditional cash transfer (CCT) schemes in Latin American and African countries, which have lifted millions of people around the world from poverty (Raquiza, 2018; Fiszbein, et al., 2009).

Same with most of the Conditional Cash Transfer Programs being implemented in different countries, it is among the targets of the Philippine 4Ps to break the cycle of poverty and address the needs of the marginalized by supplementing the household beneficiaries' financial resource through the cash grant.

The 4Ps is considered as the largest social protection program in the Philippines with the widest coverage of the marginalized households (Department of Social Welfare and Development, 2009). The Department of Social Welfare and Development (DSWD) is the government agency tasked to spearhead the selection of the grantees and the provision of cash grants to eligible beneficiaries (Reyes et al., 2013) who have affirmed that they will abide to, and satisfy all the conditions. These include regular health check-ups for pregnant women and children aged 0 to 5; deworming of school children aged 6 to 14 twice a year; enrolment of children in daycare, elementary, and secondary schools with at least $85 \%$ class attendance (Fernandez and Olfindo, 2011). Aside from these, the parent-beneficiaries are required to attend mother's class and family development sessions designed to enhance their skills and understanding on core family values and parental responsibilities, and to encourage them to be involved in community activities (Mangahas et al., 2018).

To easily and systematically identify eligible beneficiaries from across the country, the DSWD introduced a survey and data collection system known as LISTAHANAN or National 
Household Targeting System for Poverty Reduction (NHTS-PR) (Hayakawa, et al., 2015). Enumerators hired by the department go to every household to collect information regarding the socio-demographic profile of the residents similar to what enumerators of Philippine Statistics Authority (PSA) do but with focus on identifying the socioeconomic needs of the members of the family. The data is processed and analyzed to come up with a list of eligible beneficiaries or the disadvantaged families with pregnant mothers or school-aged children (Department of Social Welfare and Development, 2011).

Many families have benefitted from the program since its launch (Catubig et al., 2015). The purpose of the 4Ps program to promote social development as a response to the immediate needs of extremely poor families has been effective in breaking the intergenerational cycle of poverty in many regions of the country (Dungog-Cuizon et al., 2016).

Based on records, the 4Ps has been implemented to all regions in the Philippines comprised of 79 provinces, 143 cities, and 1,484 municipalities. As of August 26, 2015, there are 4, 353, 597 active household beneficiaries. Of which, 570, 056 are Indigenous Peoples' households while 217, 359 have at least one member who is considered a Person with Disability (PWD). School children ages 0 to 18 , who are among the primary recipients or beneficiaries of the program account for 10, 235, 658 of the total surveyed population with an average of two to three children per household (Fernandez and Olfindo, 2011).

Cash grants are provided to beneficiaries in two ways: 1) Health Grant of P500.00 per household for every month, or a total of $\mathrm{P} 6,000.00$ per year; 2) Education Grant of $\mathrm{P} 300.00$ per child on each month for ten months or a total of $\$ 3,000.00$ per year. An eligible household may register up to three children (Catubig et al., 2015). Hence, given this set-up, a household with three children may receive $\mathrm{P} 1,400.00$ monthly cash grant or a total of P15,000.00 every year for a maximum of five years if they are qualified to receive both health and educational grants which are provided through bank payment scheme mainly, cash card. The amount of cash grants the beneficiary households are entitled to receive are also compared and verified against the household information database (Fernandez, 2009).

Their compliance is checked and verified by the DSWD during the reporting period prior to the release of the payment. Non-compliance to any of the conditionalities also mean non-inclusion on the list of eligible beneficiaries for that month. Continued non-compliance (third offense) will result in termination of payments and suspension from the program (Fernandez and Olfindo, 2011).

The provision of the cash grant is expected to permit children from family-beneficiaries to finish primary or secondary schooling and therefore find decent jobs that will inhibit the passing of poverty to the next generation. There are also studies which attests to the positive effect of social programs including 4Ps to the academic performance and in minimizing the dropout rate of student-beneficiaries in both the primary and secondary schools in the other countries and in the Philippines (Raymundo, 2007; Reyes et al., 2015; Harouman, 2012).

Some students of the Calaba National High School in Brgy. Calaba, San Isidro, Nueva Ecija, Philippines fortunately qualified for the grant. In fact, for School Year 2017-2018 alone, two 
hundred four (204) students were included in the roster of educational cash grant beneficiaries.

The government invested billions to sustain the program and to provide monetary assistance to the deserving students who belong to the disadvantaged families. This situation sparked the interest of the researchers to study the effect of the 4Ps on the academic performance of the students of Calaba National High School who are direct beneficiaries of the grant. The study will also look into the effect of the program on influencing the students to strive for more as well as the perceived benefits of the program on the improvement of the quality of beneficiaries' lives.

\subsection{Objectives of the Study}

The study seeks to evaluate the effects of the Pantawid Pamilyang Pilipino Program (4Ps) on the academic performance of the student beneficiaries of Calaba National High School in San Isidro, Nueva Ecija, Philippines. Specifically, this study seeks to:

1) Determine the perceived effects of the program to the beneficiaries in terms of:

1.1. Minimizing financial burden;

1.2. Helping student beneficiaries focus on their studies; and

1.3 Improving the students' academic performance

2) Establish whether the assistance received by the student beneficiaries contributed to the improvement of their academic performance in terms of:

\subsection{Class attendance; and}

\subsection{General average}

3) Determine whether the program has attained its purpose of minimizing drop-out rate among students who belong to the disadvantaged families;

4) Determine whether the benefits received by the student beneficiaries from the 4Ps program have significant effect on their academic performance in school;

5) Recommend policy reforms based on the findings to improve the system.

\subsection{Hypothesis}

The benefits received by the student beneficiaries from the 4Ps program do not have significant effect on their academic performance in school.

\subsection{Theoretical Framework}

Academic performance is said to be affected by student's intrinsic and extrinsic motivations. Most theories expressed in the scholarly literatures would agree nonetheless, that motivation is comprised of the desire to act, ability to act, and one's end-goal (Ramlall, 2004).

The study used Vroom's Expectancy Motivation Theory in analyzing the effect of the 
program on the academic performance of the student-beneficiaries. The theory adopts the idea that a person's behavior results from conscious choices which are aimed towards maximizing pleasure and minimizing pain (Stecher \& Rosse, 2007). Although performance is said to be primarily based on individual factors such as personality, skills, knowledge, experience, and abilities, effort, performance, and motivation are also linked to academic success (Gbollie and Keamu, 2017).

As shown on Figure 1, the variables are grouped into Expectancy (increased effort will lead to increased performance), Instrumentality (better performance will lead to valued outcome), and Valence (importance that the individual places on the expected outcome). All these pertains to the factor which motivates an individual to perform better; thus, can be considered a predictor of actual academic performance.

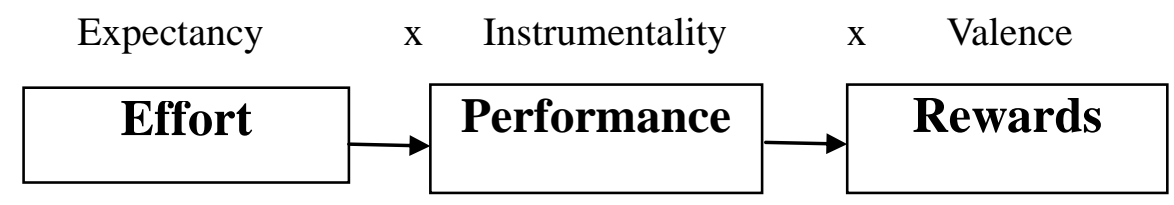

Figure 1. Vroom's Expectancy-Instrumentality-Valence Model

As applied in the study, the entitlement and suspension from the grant serves as the motivation of the students to meet the conditions. Their efforts are directed towards the ends or benefit they are likely to receive upon meeting the requirement. In so doing, their actual academic performance are expected to improve.

\subsection{Research Paradigm}

The Figure 1 below shows the framework used by the researchers to evaluate the effect of 4Ps Educational Grant to the student beneficiaries of Calaba National High School who belong to the disadvantaged families.

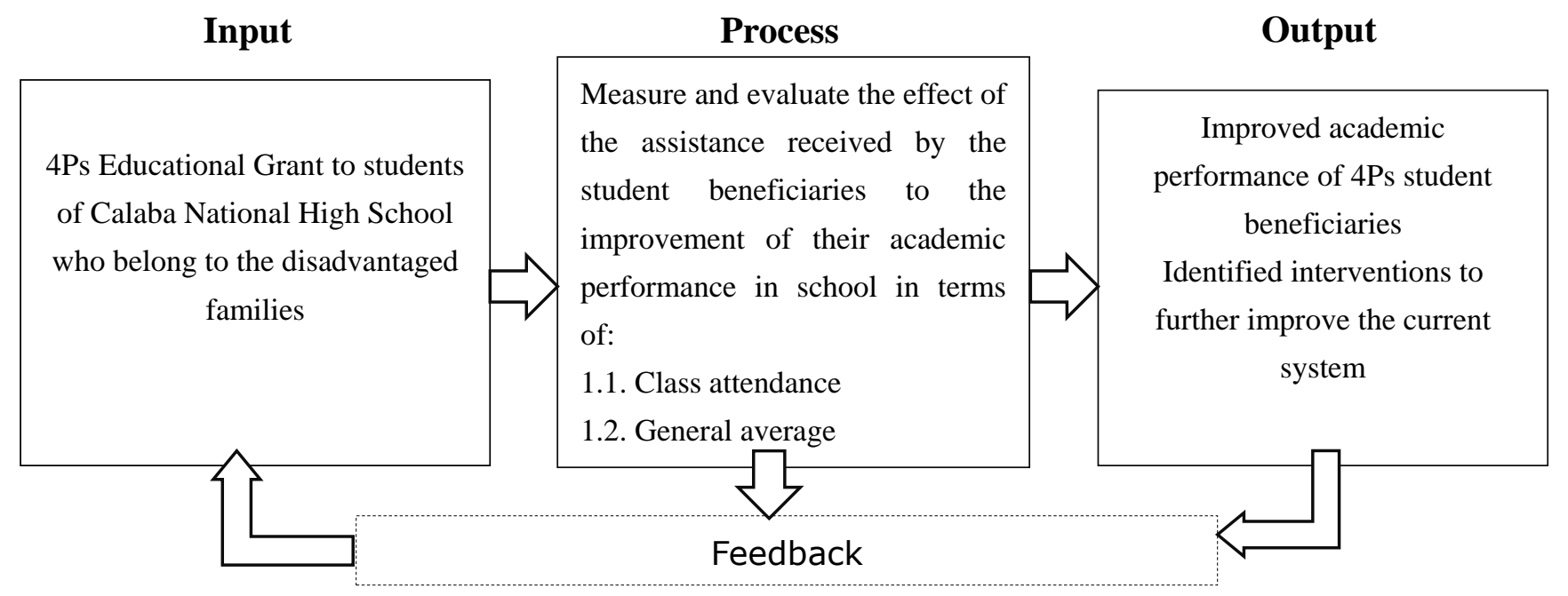

Figure 2. Conceptual Framework of the study

The Input-Process-Output framework enables the researchers to illustrate the causal 


\section{Macrothink}

relationships between identified variables such as the effect of cash grant to the academic performance of students in terms of class attendance, general average, and the perceived effects to the student beneficiaries. The result of which, will be evaluated to develop a feedback which will be used to improve current system.

\section{Methodology}

\subsection{Study Locale}

The study area is at Calaba National High School, Barangay San Isidro, Nueva Ecija, Philippines. A school which was founded in 1966 by the United States Assistance for International Development (USAID) and began with only two classrooms composed of first year and second year students. At present, the population of the school grew to eight hundred seventy one (871) high school students, one principal, one head teacher, thirty five permanent teachers, two non-teaching staff, two utility workers, and two canteen helpers.

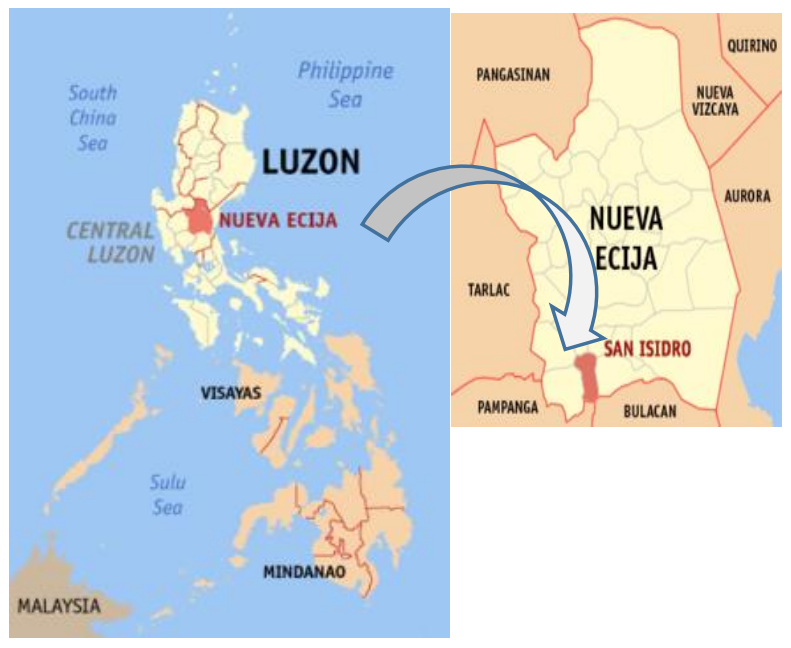

Figure 3. Map showing the locale of the study

This study was conducted to evaluate the effects of the Pantawid Pamilyang Pilipino Program (4Ps) on the academic performance of the students who are enrolled at Calaba National High School, Calaba, San Isidro, Nueva Ecija, for the School Year 2017-2018 and are currently receiving education cash grant under the 4Ps program. The students who were chosen to be part of the study came from the disadvantaged families of barangays Calaba, San Roque, and Sto. Cristo in the municipality of San Isidro, Nueva Ecija; barangay Entablado in the municipality of Cabiao, Nueva Ecija; and other nearby barangays.

\subsection{Data Gathering and Sampling Procedure}

The researcher sought permission to conduct the study from the school administrators. They were assured that the data which will be collected from the respondents would be used for academic purposes.

This study employed mixed method of research. The respondents of the study were 
purposively selected using the following criteria: 4Ps beneficiary, currently enrolled in Calaba National High School, and willing to participate in the study. Survey questionnaire in binary form were distributed to ninety-five (95) 4Ps student beneficiaries. The questionnaire is divided into two with the first part delving deeper into the profile of respondents and second part providing details as to the perceived effects and benefits of the program to the students in terms of minimizing financial burden, improving students' focus, and in improving the academic performance. Interviews were conducted and secondary data such as enrollment record and other records intended for public viewing were also visited to verify the respondents' answers. Relevant literatures were also consulted to compare and contrast the findings.

\subsection{Data Analysis}

Data collected were analyzed using descriptive statistics such as frequency and percentage. Other data collected were presented in graphical form. Results of analysis were interpreted and analyzed to draw conclusions and recommendations for policy reforms.

\section{Results and Discussion}

This section shows the analysis of data collected which include the responses made by the students on the survey questionnaire and interview. The data were tallied, analyzed, and presented in figure, tabular, or textual form.

\subsection{Profile of Respondents}

Table 1. Number of Household Members

\begin{tabular}{c|c|c}
\hline Family Size & f & \% \\
\hline Less than 5 & 33 & $35 \%$ \\
\hline $5-10$ & 55 & $58 \%$ \\
\hline More than $10 \quad$ Total & 7 & $7 \%$ \\
\hline & 95 & $100 \%$ \\
\hline
\end{tabular}

The respondents' answer on the first part of the questionnaire revealed that the household beneficiaries have an average of 5 to 10 members (58\%). This can be considered a large family and may likely affect the well-being of the members given the socio-economic status of the family-beneficiaries. Argys and Averette (2015) in their study suggest the inverse relationship between family incomes or socio-economic status and family size particularly, the increased educational attainment among children belonging to smaller families.

Table 2. Sources of Income of the Household aside from the grant

\begin{tabular}{c|c|c}
\hline Source of Income & f & \% \\
\hline Regular job/small-scale business & 73 & $77 \%$ \\
\hline By Contract & 10 & $11 \%$ \\
\hline Part-time job Total & 12 & $12 \%$ \\
\hline$\quad 95$ & $100 \%$ \\
\hline
\end{tabular}

Most respondents $(77 \%)$ said that members of their household are engaged in jobs with 
regular income or in small-scale business such as operating a variety store popularly known as "sari-sari store", or selling goods in the market. The income from said ventures are the main source of income in the household which were primarily used to support the basic needs of the family. Other families on the other hand, rely on less stable jobs which include by contract and part-time jobs as house helpers, farm workers, and product resellers.

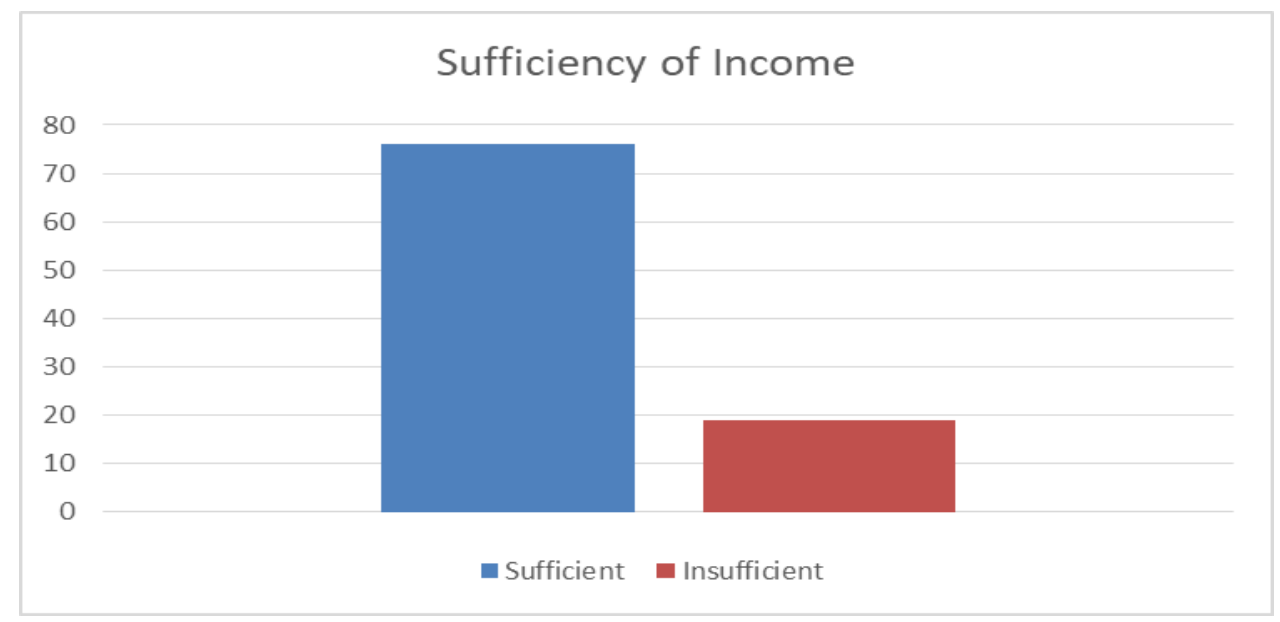

Figure 4. Sufficiency of household income as perceived by the student beneficiaries

Majority (80\%) of the respondents perceived that the income of their parents are enough to sustain the needs of the family. Most of the students who responded positively to the question are also the students who belong to the households with five to ten members. The result somehow validates the idea previously presented that the smaller the family size, the more the family is capable of supporting the needs of the members. Unfortunately, there are still families (20\%) with income that is not enough to support all the needs of the family. Hence, they are grateful to the 4Ps program as it helps with their family's finances and on their school expenses.

Table 3. Number of family members who are 4Ps beneficiaries

\begin{tabular}{c|c|c}
\hline $\begin{array}{c}\text { Number of members who are 4Ps } \\
\text { beneficiaries }\end{array}$ & $\mathbf{f}$ & $\boldsymbol{\%}$ \\
\hline 1 & 17 & $18 \%$ \\
\hline 2 & 22 & $23 \%$ \\
\hline 3 & 32 & $34 \%$ \\
\hline 4 & 18 & $19 \%$ \\
\hline 5 & 5 & $4 \%$ \\
\hline Unsure & 1 & $1 \%$ \\
\hline & 95 & $100 \%$ \\
\hline
\end{tabular}

The responses made by $34 \%$ of the student beneficiaries agree with the present arrangement of 4Ps or the condition of three beneficiaries per family. Some households have fewer school-aged children or with no pregnant woman at the time of assessment while others with more than three beneficiaries belong to an extended family. 
Table 4. Monthly cash grant received by the household

\begin{tabular}{|c|c|c|}
\hline $\begin{array}{l}\text { Monthly cash grant received by the } \\
\text { household }\end{array}$ & $\mathbf{f}$ & $\%$ \\
\hline $\mathrm{P} 1,000.00-\mathrm{P} 1,900.00$ & 19 & $20 \%$ \\
\hline Р2,000.00-尹3,900.00 & 44 & $46 \%$ \\
\hline Р4,000.00-尹5,900.00 & 8 & $9 \%$ \\
\hline P6,000.00-Р7,900.00 & 24 & $25 \%$ \\
\hline Total & 95 & $100 \%$ \\
\hline
\end{tabular}

Most respondents (46\%) confirmed that their family receive a total of $\mathrm{P} 2,000.00-\mathrm{P} 3,900.00$ per month from the program. On the other hand, based on the interview, almost $80 \%$ of students said that they use the money for school essentials while nearly $13 \%$ spend the money for personal needs. Some $7 \%$ of respondents said that because of tight family budget they are from time to time obligated to use the money for food and transportation expenses. It is a manifestation that the cash grant is used by the beneficiaries not only for school-related expenses but for day-to-day necessities or as allowance.

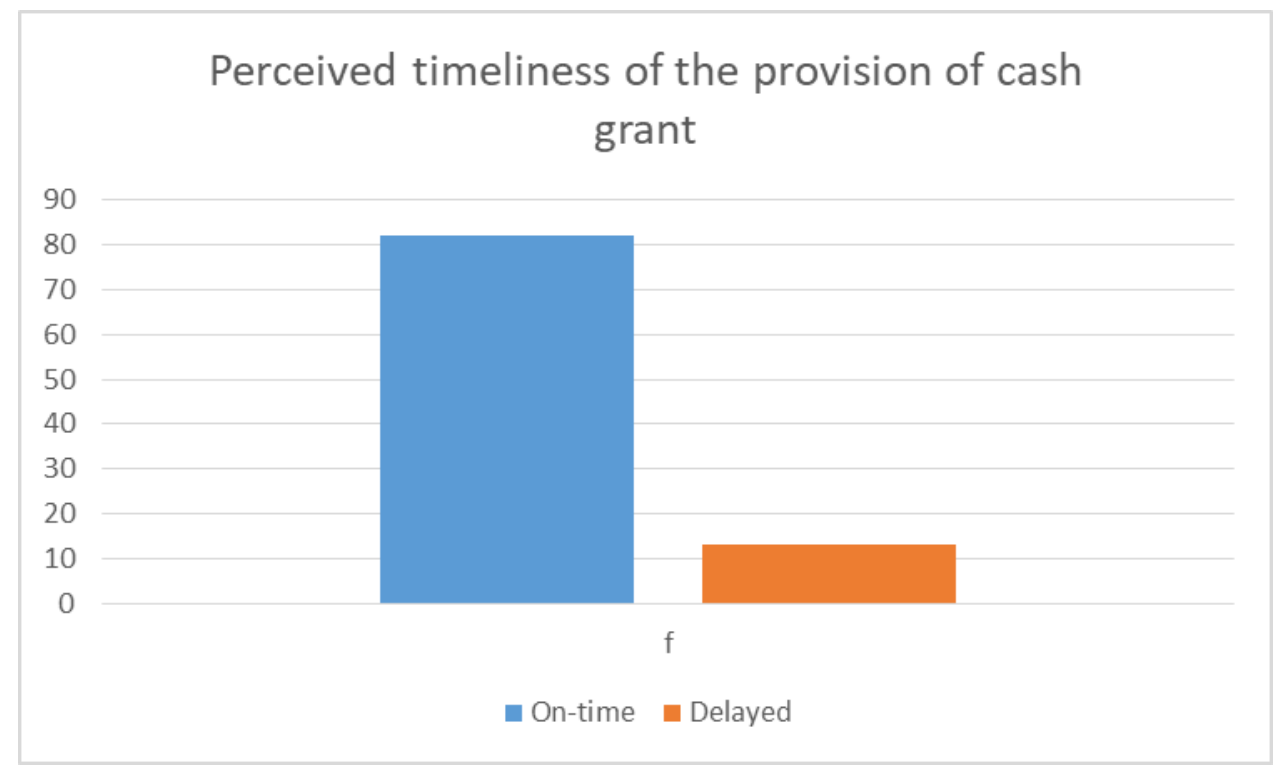

Figure 5. Timeliness of the provision of cash grant

Out of 95 respondents, 82 or nearly $86 \%$ have agreed that they have received the assistance from the program on time; and 13 respondents or almost $14 \%$ revealed that there are instances when they do not receive the assistance on time. The respondents made by the student beneficiaries reflect the gaps or inefficiency of program implementers in disbursing the grant on time. Most, if not all of the beneficiaries rely on the grant. Hence, the need to revisit the system to identify the lapses that leads to the delay in the grant distribution which unfortunately, may affect the beneficiaries especially those who uses the money for food and transportation expenses. 


\section{Macrothink}

Journal of Public Administration and Governance

ISSN 2161-7104

2019, Vol. 9, No. 2

3.2 Effects and Perceived Benefits of Entitlement to Pantawid Pamilyang Pilipino Program $(4 P s)$

This section reflects the respondents' perception of the effects and benefits of the student's entitlement to the Pantawid Pamilyang Pilipino Program (4Ps) particularly in minimizing the financial burden of the family; in helping the students focus more in their schooling; and in improving the academic performance of the students.

\subsubsection{In Minimizing Financial Burden}

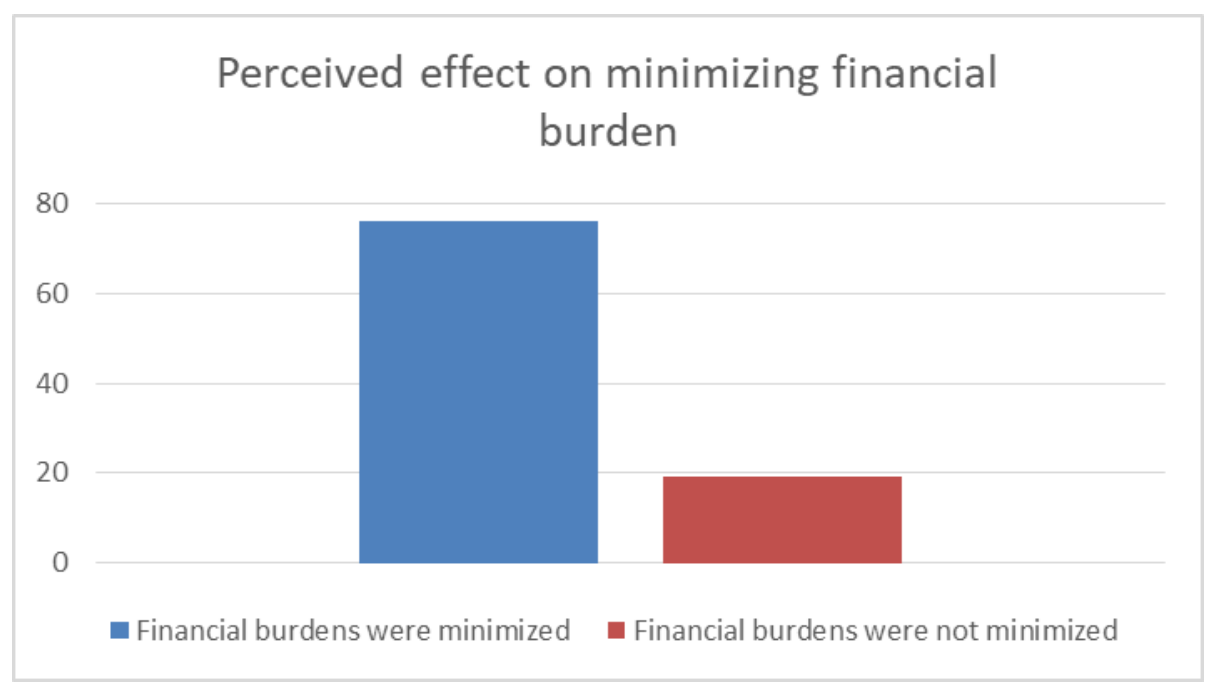

Figure 6. Perceived effect of entitlement to 4Ps program in minimizing financial burden

Eighty percent $(80 \%)$ of the respondents agreed that because of the grant, they now have lesser financial worries or burden. Because of the grant, they now have the means to buy school supplies. Others, or 23 respondents said that the grant did not minimized their financial burdens since portions of the grant are still used for the purchase of medicines and necessities of other family members. In a related study conducted by Dela Tore (2016), the program has helped increase parents' promptness in paying school dues from $64.30 \%$ to $88.00 \%$ after the implementation of the program.

\subsubsection{In Helping Student Beneficiaries Focus on Their Studies}

Interview results revealed that some students have had hard time focusing on their studies because of hunger or financial worries. Because of limited budget, some cannot afford to buy snacks while others go to school without eating breakfast. On the other hand, there are also students who allot their allowance for school expenses. These were the common scenarios prior to their inclusion to the 4Ps beneficiaries. 


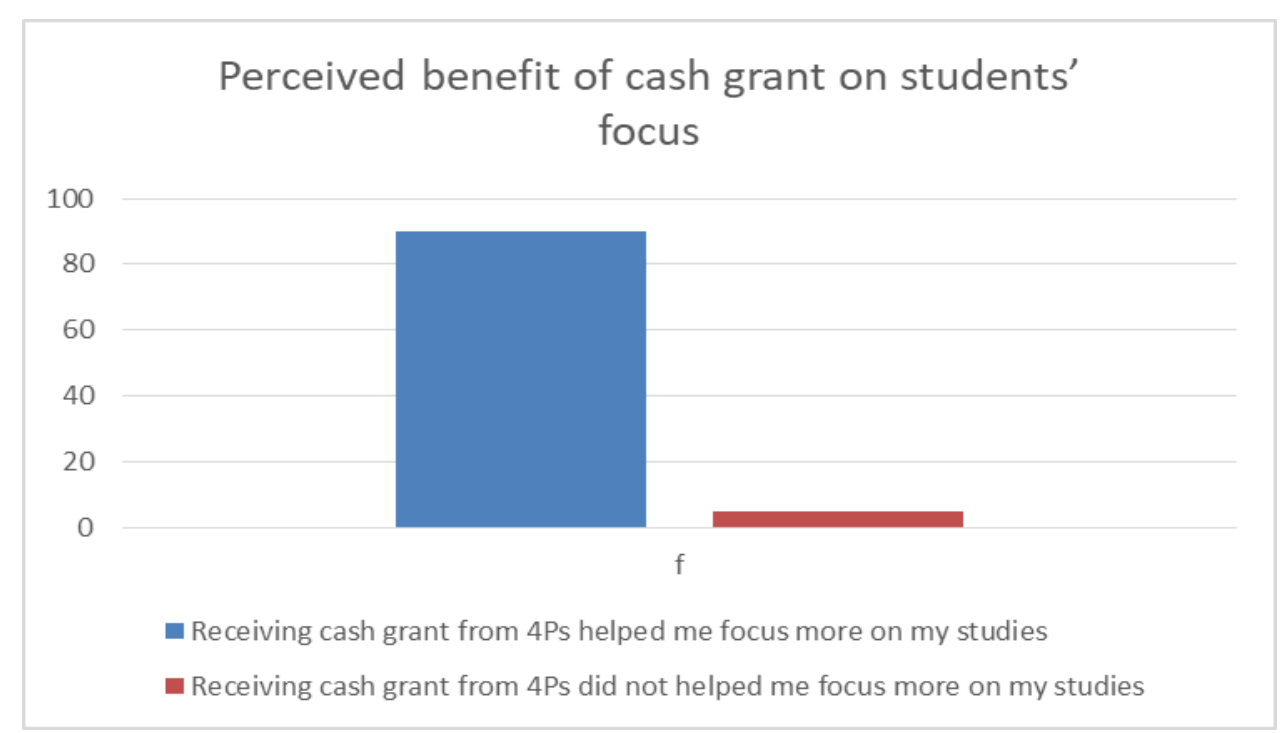

Figure 7. Perceived benefit of cash grant on students' focus

Nonetheless, after receiving cash grant through the 4Ps, ninety five percent (95\%) of the respondents, as reflected on Figure 6, believed that they were able to focus more on their studies. Somehow, the result express the contribution of 4Ps towards improvement of the lives of economically-deprived Filipino Youths. However, the school administrators, implementers, and evaluators of the program should still consider the predicament of the remaining $5 \%$ of students who believes that the grant do not fully help them focus more on their studies.

\subsubsection{In Improving the Students' Academic Performance}

Out of the 95 respondents, 74 or almost $78 \%$ of the respondents have agreed that their academic performance did improved after receiving cash grant from 4Ps. Eleven (11) respondents, or almost $12 \%$ have disagreed; and 10 respondents or nearly $10 \%$ are not sure if the improvement in their academic performance is mainly because of the grant.

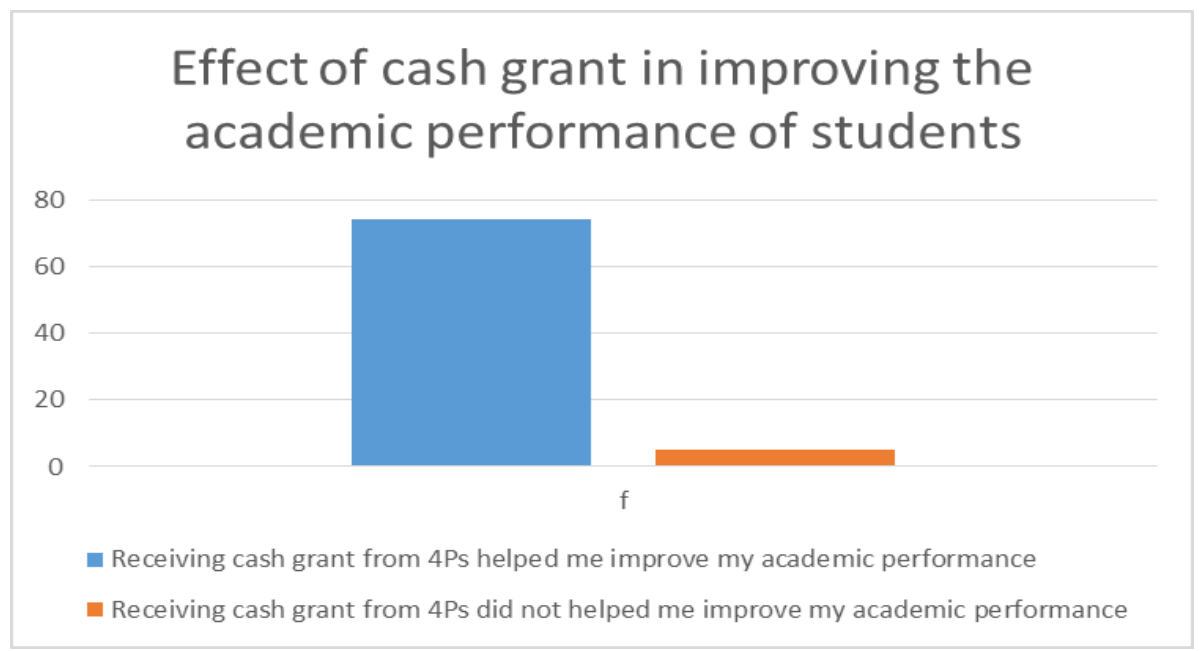

Figure 8. Perceived benefit in terms of improving the academic performance 
Eighty six (86) respondents admitted that they became more excited in going to school now that they are receiving grants. Furthermore, seventy one (71) respondents or almost $74 \%$ said that they now submit their projects and other requirements on time because they can now afford to buy office supplies.

Responses made by the students therefore supports the idea that the 4Ps did helped in improving the academic performance of the students. The findings are consistent with the work of Reyes et al. (2011) in which the rate of school participation of children increased by 3 to 4.6 percent and around 96.3 in terms of school attendance.

\subsection{Comparison of Students' Academic Performance Before and After Cash Grant From 4Ps}

Table 5. Comparison of students' academic performance before and after receiving 4Ps cash grant

\begin{tabular}{c|c|c|c|c}
\hline & \multicolumn{2}{|c|}{ Before } & \multicolumn{2}{c}{ After } \\
\hline General Average & f & \% & f & \% \\
\hline 80 and below & 24 & $25 \%$ & 12 & $13 \%$ \\
\hline $81-84$ & 45 & $47 \%$ & 36 & $38 \%$ \\
\hline $85-89$ & 25 & $26 \%$ & 34 & $35 \%$ \\
\hline 90 and above & 1 & $1 \%$ & 13 & $14 \%$ \\
\hline Total & 95 & $100 \%$ & 95 & $100 \%$ \\
\hline
\end{tabular}

To triangulate the data, the researchers collected secondary data by requesting for a copy of the General Average of Students before and after receiving cash grant. Based on the collected data, from $1 \%, 14 \%$ of the students got a grade of 90 and above after receiving cash grant. This result reinforces the previous data indicating the significant improvement on the student's academic performance after being enlisted as 4Ps beneficiaries and upon receipt of cash grant. Although it was previously discussed in this paper that the program did improve the lives of students in other aspects in terms of financial aspect and perception in attending classes, the data however, also reflects that there are students whose grades remain on the 80 and below bracket. Hence, mirrors the inefficacy of the program in improving the status of students in terms of grade point average.

\subsection{Drop-out Rate of Student Beneficiaries From S.Y. 2014-2018}

Table 6. Drop-out rate from S.Y. 2014-2018

\begin{tabular}{c|c}
\hline School Year & Percentage \\
\hline $2017-2018$ & $2.21 \%$ \\
\hline $2016-2017$ & $3.46 \%$ \\
\hline $2015-2016$ & $5.83 \%$ \\
\hline $2014-2015$ & $4.72 \%$ \\
\hline
\end{tabular}

The collected data from the area of study revealed that there has been a reduction on the student's drop-out rate from School Year 2014 to 2018. From years 2016 to 2018, when many students were enlisted as 4Ps beneficiaries, there has been a reduction on the percentage of 
students who dropped out of school because of financial constraints.

\subsection{Hypothesis}

Table 7. Result of the Analysis of Variance

\begin{tabular}{lccc} 
ANOVA & & & \\
\hline \multicolumn{1}{c}{ Source of Variation } & $F$ & P-value & F crit \\
\hline Between Groups & 6.814394 & 0.01578 & 4.256495 \\
Within Groups & & & \\
Total & & & \\
\hline
\end{tabular}

The Analysis of Variance (ANOVA) was used to determine the significant relationship between the variables. The result of computed statistics rejects the null hypothesis that there is no significant difference on the academic performance of the students before and after entitlement to the program. The result highlights the effectiveness of the program in bringing change onto the lives of the student-beneficiaries. The result also confirms the idea in the theoretical framework used in the study which assumes that the students' efforts, performance, and behavior are influenced by the importance they place on the desired outcome. In this case, to satisfy the conditionalities and remain eligible for the cash grant which have positive effect on the socio-economic status of their family.

\section{Summary, Conclusion, and Recommendations}

\subsection{Summary}

Majority of the student-beneficiaries belong to big, disadvantaged families. Some do not even have sufficient resources to sustain their basic needs. There were families that cannot afford to send their children to school. However, most of the respondents, in spite their enrolment to the program believe on the insufficiency of the grant to support their needs.

Nonetheless, it is noteworthy that the educational cash grant is still being used to sustain the students' school needs and other expenses. Another positive impact of the program is that it lessened the family-beneficiaries" financial worries thereby helping students focus more on their schooling. Some of the students who became beneficiaries of the 4Ps have improved their academic performance with average grades higher than $85 \%$ to $90 \%$. Also, majority of the beneficiaries feel more excited to attend school and participate in the class activities.

\subsection{Conclusion}

The 4Ps program has partly satisfied its objective of helping the student-beneficiaries to improve their academic performance. The program also instilled in the minds of the students the value of education as one of the best investments for a brighter future. The grant kindles the 4Ps beneficiaries' interest in attending classes, better than the time prior to receipt of grant. The opportunity also reduced the prevalence of children who are forced to stop from school to secure their family's financial needs. The reduction of cases of child labor is a good indication that the 4Ps program is successful in its campaign to improve the lives of the 
disadvantaged families and for the parent-beneficiaries to realize the importance of education as an element of success.

With this great effort of the government to help the poor student-beneficiaries through the Pantawid Pamilyang Pilipino Program (4Ps), it is a good indication that in the future the government will produce well-educated citizen that are imperative for a more productive country and society.

The findings support the result of the impact evaluation of the DSWD in 2011 reflecting the positive impacts of the program on the recipients. The cash grants supplemented the household beneficiaries' incomes while the conditionalities led to the improvement of children's education.

\subsection{Recommendations}

From the analysis of all data collected and the responses made by the student-beneficiaries, the following recommendations have been arrived at:

1. The government may consider extending the age limit of the beneficiaries to sustain their schooling until the time they graduate especially now that two years have been added to the secondary education;

2. The DSWD and the local government units should intensify the implementation and the scope of the livelihood programs to serve as additional source of income for family-beneficiaries;

3. There is a need for the concerned agencies to review the budget and disbursement schemes for the timely release of the grant;

\section{References}

Argys, L., \& Averette, S. (2015). The Effect of Family Size on Education: New Evidence from China's One Child Policy; Institute for the Study of Labor (IZA) Discussion Paper No. 9196

Catubig, M., Villano, R., \& Dollery, B. (2015). Payment Schemes in Conditional Cash Transfer Programs: The Case of 4Ps in the Davao Region, Philippines. Administrative Sciences, 5(4), 240-259. https://doi.org/10.3390/admsci5040240

Dela, T. B. (2016). Financing Education through the Pantawid Pamilyang Pilipino Program (4Ps); International Journal of Humanities and Social Science, 6(5).

Department of Social Welfare and Development (2009). Operations Manual for the Pantawid Pamilyang Pilipino Program.

Department of Social Welfare and Development (2011). National Household Targeting System for Poverty Reduction; Retrieved from http:// nhts.dswd.gov.ph/

Dungog-Cuizon, A., \& Cuizon, C. (2016). The Pantawid Pamilyang Pilipino Program (4Ps): A Philippine Open Government Partnership (OGP) Initiative. CNU Journal of Higher Education, 10, 46-58. 
Fernandez, F., \& Olfindo, R. (2011). Overview of the Philippines' Conditional Cash Transfer Program: The Pantawid Pamilyang Pilipino Program (Pantawid Pamilya). Philippine Social Protection Note.

Fernandez, L. (2009). Targeting Mechanism Used to Select Beneficiaries for the Pantawid Pamilyang Pilipino Program, Social Welfare and Development Journal, 3(1), 11-16.

Fiszbein, A., Schady, N., Ferreira, F., Grosh, M., Kelleher, N., Olinto, P., \& Skoufias, E. (2009). "Conditional Cash Transfers: Reducing Present and Future Poverty", World Bank, Washington, DC. https://doi.org/10.1596/978-0-8213-7352-1

Gbollie, C., \& Keamu, H. P. (2017). Student Academic Performance: The Role of Motivation, Strategies, and Perceived Factors Hindering Liberian Junior and Senior High School Students Learning; Education Research International, Volume 2017, Article ID 1789084, 11 pages, https://doi.org/10.1155/2017/1789084

Harounan, K., De Walque, D., \& Alderman, H. (2012). Educational and Child Labour Impacts of Two Food-for-Education Schemes: Evidence from a Randomised Trial in Rural Burkina Faso. Journal of African Economies, 21(5), 723-60.

https://doi.org/10.1093/jae/ejs010

Hayakawa, M., Van de Brink, R., \& Posarac, A. (2015). Why Does the Conditional Cash Transfer Program Matter in the Philippines? Philippines Social Protection Note, (7).

Iarmosh, I. (2013). How Family Size affects Children's Educational Outcomes: Evidence for Russia.

Mangahas, T., Casimiro, R., \& Gabriel, A. (2018) Economically Challenged Women in Disaster Risk Management: Toward a Resilient Filipino Community. Open Journal of Ecology, 8, 42-56. https://doi.org/10.4236/oje.2018.81004

Ramlall, S. (2004). Review of Employee Motivation Theories and Their Implications for Employee Retention with Organizations. Journal of American Academy of Business, 5(1/2), 52-64.

Raquiza, M. (2018). The conditional cash transfer program. Routledge Handbook of the Contemporary Philippines.

Reyes, C., Tabuga, A., Asis, R., \& Mondez, M. B. (2014). Child Poverty in the Philippines. Discussion Paper Series No. 2014-33

Reyes, C., Tabuga, A., Mina, C., \& Asis, R. (2015). Promoting Inclusive Growth Through the 4Ps. Discussion Paper Series No. 2015-01

Reyes, C., Tabuga, A., Mina, C., Asis, R., \& Datu, M. B. (2011). Dynamics of Poverty in the Philippines: Distinguishing the Chronic from the Transient Poor; Philippine Institute for Development Studies; Discussion Paper Series No. 2011-31.

Stecher, M., \& Rosse, J. (2007). Understanding reactions to workplace injustice through process theories of motivation: A teaching module and simulation. Journal of Management 
Education, 31(6), 781. https://doi.org/10.1177/1052562906293504

\section{Copyright Disclaimer}

Copyright for this article is retained by the author(s), with first publication rights granted to the journal.

This is an open-access article distributed under the terms and conditions of the Creative Commons Attribution license (http://creativecommons.org/licenses/by/4.0/). 